\title{
ANALISIS VIDEO COMMENTS TO VIDEO LIKES RATIO TIKTOK PADA 5 GAMER INDONESIA YANG MEMILIKI JUTAAN PENGIKUT DI YOUTUBE
}

\author{
Mateus Do Nascimento Pires \\ teo.mateus97@gmail.com
}

\begin{abstract}
TikTok is a social media application launched by a Chinese company. TikTok allows users to create 15 -second videos accompanied by music, filters, and several other creative features. In Indonesia, there are 30.7 million active users, which makes Indonesia the country with the largest TikTok users in the world. The large number of active TikTok users in Indonesia can certainly provide an opportunity for gamers to make the TikTok platform a social media marketing platform. There are 5 Indonesian gamers who use TikTok as a marketing platform, namely: Jess No Limit, Frost Diamond, Miaw Aug, Dylan Pross, Budi Gaming. The purpose of this study is to calculate the credibility of the performance of the TikTok 5 Gamer Indonesia account which has millions of followers on YouTube. The method used for this research is quantitative exploratory method. The results of this study show that Jess No Limit is ranked first and has the best account performance credibility among all 5 gamers who have millions of followers on youtube.
\end{abstract}

\begin{abstract}
ABSTRAK
TikTok merupakan aplikasi sosial media yang diluncurkan oleh perusahaan asal Tiongkok. TikTok memungkinkan penggunanya membuat video berdurasi 15 detik yang disertai dengan musik, filter, dan beberapa fitur kreatif lainnya. Di Indonesia terdapat 30,7 juta pengguna yang aktif dimana menjadikan Indonesia sebagai negara dengan pengguna TikTok terbesar di dunia. Banyaknya jumlah pengguna TikTok yang aktif di Indonesia tentu dapat memberikan peluang bagi gamer untuk menjadikan platform TikTok sebagai platform social media marketing. Adapun 5 Gamer Indonesia yang memanfaatkan TikTok sebagai platform marketing, yaitu : Jess No Limit, Frost Diamond, Miaw Aug, Dylan Pross, Budi Gaming. Tujuan dari penelitian ini yaitu untuk menghitung kredibilitas dari performa akun TikTok 5 Gamer Indonesia yang memiliki jutaan pengikut di youtube. Metode yang digunakan untuk penelitian ini yaitu metode eksploratif kuantitatif. Hasil dari penelitian ini menunjukan bahwa Jess No Limit mendapatkan
\end{abstract}


peringkat pertama dan memiliki kredibilitas performa akun yang paling baik di antara semua 5 gamer yang memiliki jutaan pengikut di youtube.

Keyword : Credibility Account TikTok ; Social Media Marketing ; Social Media TikTok ; Video Comments to Video Likes Ratio ; Gamer Indonesia.

\section{PENDAHULUAN}

Perkembangan teknologi yang sangat pesat di era globalisasi saat ini telah memberikan banyak manfaat dalam kemajuan di berbagai aspek sosial, salah satunya adalah berkomunikasi menjadi lebih mudah dan cepat. Seiring dengan pesatnya perkembangan teknologi, komunikasi antar remaja di lingkungan sosial maupun di lingkungan sekolah sekarang sudah menguasai ilmu teknologi yang mengunakan jaringan internet, yaitu media sosial. Beberapa peneliti menjelaskan bahwa istilah media sosial mengacu pada berbagai layanan berbasis internet dan mobile yang memungkinkan pengguna untuk dapat bergabung dalam percakapan daring, berkontribusi dalam konten yang dibuat oleh pengguna, atau bergabung dengan komunitas daring.

Di Indonesia Pada tahun 2018 aplikasi ini dinobatkan sebagai aplikasi terbaik di Play store yang dimiliki oleh Google. Tidak hanya itu, Tik Tok juga menjadi kategori aplikasi paling menghibur (Imron 2018). Pada Juli lalu Aplikasi buatan China itu sempat diblokir oleh Kementrian Komunikasi dan Informatika (Kominfo) di pertengahan 2018, alasannya karena adanya konten-konten yang negatif, terutama bagi anak-anak. Pemblokiran pada aplikasi ini hanya berlangung seminggu, mulai 3-10 Juli 2018. Menurut laporan dari Sensor Tower, aplikasi ini diunduh 700 juta kali sepanjang tahun 2019. Hal ini membuat Tik Tok dapat mengungguli sebagian aplikasi yang berada dibawah naungan Facebook Inc. aplikasi ini menempati peringkat ke dua setelah Whatsapp yang memiliki 1,5 miliar pengunduh (Kusuma 2020).

Aplikasi ini banyak digunakan oleh berbagai macam orang dari segala umur tidak menutup kemungkinan terdapat konten yang mengandung unsur negatif di dalamnya. Dimana dapat membahayakan untuk perkembangan mental penggunanya yang rata-rata remaja yang berusia di bawah 18 tahun karena belum stabilnya dari segi pemikiran. Masa remaja merupakan masa peralihan dari anak-anak menuju dewasa dalam hal ini terdapat 
perkembangan baik itu secara fisik maupun mental. Terdapat batasan usia yang umunya digunakan oleh ahli antara 12 sampai 21 tahun, dapat dikelompokkan antara lain, remaja awal memiliki rentang usia 12-15 tahun, remaja pertengahan 15-18 tahun dan remaja akhir yang memiliki rentang usia 18- 21 tahun (S. D. Putri and Azeharie 2021).

Aplikasi ini banyak digemari oleh para remaja, anak kecil, bahkan sampai pada orang dewasa yang merasa mmbutuhkan hiburan. Konon aplikasi ini memiliki nama lain aplikasi "goblok". Banyaknya anak muda maupun dewasa yang membuat dan memposting video diberbagai platform media sosialnya membuat tidak hanya aplikasi ini semakin popular namun orang yang menggunakan aplikasi "goblok" ini ikut. Tik Tok memiliki ciri khas sendiri. Video yang diunggah oleh Tik Tok memiliki "watermark" berupa username yang membedakannya dengan aplikasi lainnya (D. Putri and Adawiyah 2020).

Banyak penyebab yang di timbulkan oleh efek media sosial yang mendorong orang memiliki perilaku komunikasi tertentu, salah satunya media sosial TikTok yang merupakan aplikasi media sosial yang dapat memenuhi kebutuhan yang diinginkan penggunanya dan merupakan salah satu alat komunikasi yang memang berbeda dengan media sosial lainnya. Media sosial TikTok merupakan media sosial yang sedang trend saat ini dibandingkan dengan media sosial lain yang sudah banyak digunakan oleh orang-orang.

Dalam media Tiktok juga memiliki beberapa gamer ternama yang sering diikuti oleh para followers untuk melihat konten - konten yang mereka ciptakan sebagai hiburan. Pencarian hiburan ini tidak terlepas dari kebiasaanmasyarakat Indonesia yang suka melihat sesuatu yang menarik dan juga viral. Sehingga, Aplikasi Tik Tok saat ini lebih banyak digunakan sebagai ajang untuk memamerkan diri atau yang sekarang biasa disebut eksistensi diri. Ada juga mengikuti kegiatan para selebritas serta sampai menjadi motivasi dan sumber inspirasi bagi pengikutnya. Terdapat akun Tiktok gamer youtube yang memiliki jutaan pengikut di youtube, diantaranya : Jess No Limit, Frost Diamond, Miaw Aug, Dylan Pros, Budi Gaming

Berdasarkan hal - hal tersebut, penulis memiliki minat untuk menganalisis video comment to video likes ratio Tiktok pada 5 gamer yang memiliki jutaan pengikut di youtube. Dalam mengetahui kredibilitas performa dari akun Tiktok gamer menggunakan video comment to video likes. 
Tujuan penulisan ini untuk menganalisis video comment to video likes ratio Tiktok pada 5 gamer Indonesia yang memiliki jutaan pengikut di youtube. Manfaat penulisan ini mengetahui seberapa baiknya performa dari akun tiktok para gamer yang memiliki jutaan pengikut di youtube

\section{TINJAUAN PUSTAKA}

Perkembangan bidang teknologi saat ini terjadi begitu pesat. Melalui perkembangan yang terjadi dari waktu ke waktu menimbulkan banyaknya aplikasi - aplikasi serta platform media sosial yang bermunculan. Aplikasi yang sangat diminati oleh masyarakat saat ini diantaranya adalah TikTok, Instagram, Twitter, WhatsApp dan yang lain sebagainya. Seiring berjalannya waktu, aplikasi sosial media tersebut dapat menjadi candu bagi kalangan masyarakat. Tidak hanya kalangan remaja yang menggunakan aplikasi sosial media, orang tua bahkan anak-anak juga aktif menggunakan aplikasi sosial media tersebut.

Tiktok merupakan bagian dari new media yang memiliki perkembangan terpesat dibandingkan dengan kategori new media yang lainnya seperti facebook, Instagram, YouTube, dan Twitter. Dari sekian banyak aplikasi sosial media, TikTok menjadi aplikasi yang memiliki pengguna aktif terbanyak. TikTok merupakan jejaring sosial media dalam bentuk video yang umumnya berdurasi 15 detik. Pada aplikasi TikTok pengguna dapat membuat video dengan filter-filter yang spesial serta menggunakan lagu yang sedang trending. Selain itu, pengguna dapat membagikan video yang dibuat ke aplikasi lain seperti Instagram atauoun. Salah satu ciri khas sosial media TikTok adalah halaman utamanya yang Bernama For Your Page atau FYP. Pengguna yang cukup sering ditayangkan dalam FYP dapat menjadi populer dan memiliki banyak pengikut, yang biasa disebut sebagai seleb TikTok (S. D. Putri and Azeharie 2021).

Di Indonesia, fenomena anak muda dalam menggunakan TikTok menunjukan antusiasme yang sangat massif. Meraka berlomba membangun identitas demi mendapatkan citra yang diinginkan, seperti dipuji dan dikenal oleh banyak orang(Agustina and Sari 2021). Aplikasi TikTok semakin populer sejak diluncurkan tahun 2016. Bahkan TikTok telah mencetak berbagai macam prestasi, salah satunya yaitu menyalip pendapatan iklan digital di negatanya yaitu pendapat Google China, Patio (I Putu Hendika Permana and Ni Putu Suci Meinarni 2021). 
Aplikasi TikTok tidak hanya digunakan untuk membuat konten video dengan tujuan menghibur pengguna lainnya. Aplikasi TikTok juga dapat dijadikan peluang bagi brand atau perusahaan sebagai platform social media marketing. Penelitian (Purnamasari and Tutiasri 2021) menyatakan bahwa TikTok berpengaruh positif dan signifikan terhadap minat beli atau berbelanja secara online. Sehingga dengan ini, TikTok mampu memberikan peluang yang sangat tinggi bagi perusahaan-perusahaan dalam melakukan digital marketing.

TikTok dirasakan memiliki kekuatan ataupun pengaruh dalam industri, sehingga menimbulkan kualitas akun yang menentukan strata maupun kredibilitas pemilik akun. Kredibilitas akun TikTok merupakan suatu hal yang cukup penting untuk berbagai kepentingan. Kredibilitas sebuah akun TikTok dapat diukur dari tingkat performa yang dihasilkan secara matematis. Dalam mengukur performa diperlukan skala pengukuran yang tertuang ke dalam rasio.

\section{METODE PENELITIAN}

Penelitian ini menggunakan metode eksploratif kuantitatif untuk mengetahui kredibilitas dari performa akun TikTok 5 Gamer Indonesia yang memiliki jutaan pengikut di youtube. Metode eksploratif merupakan metode penelitian yang memiliki tujuan untuk melakukan eksplorasi atau memperdalam pengetahuan dan ide-ide baru mengenai suatu hal yang baru, guna merumuskan permasalahan secara terperinci (Maryam, Isrok'atun, and Aeni 2016).

Tujuan dari penelitian ini yaitu mengetahui nilai kredibillitas dari performa akun TikTok 5 Gamer Indonesia yang memiliki jutaan pengikut di youtube. Ada beberapa langkah yang dilakukan penelitian ini, sehingga mampu menemukan peringkat pertama akun TikTok Vendor Smartphone di Indonesia yang memiliki performa terbaik. Langkah-langkah yang dilakukan pada penelitian ini, diantaranya adalah :

\section{Melakukan Eksplorasi Pada Website Untuk Menentukan Objek yang Akan Dianalisa.}

Eksplorasi ini dilakukan pada sejumlah halaman website yang menyediakan informasi mengenai objek yang akan digunakan untuk penelitian. Setelah melakukan ekslorasi selesai, peneliti menemukan nama-nama gamer di Indonesia yang akan dijadikan objek 
analisa. Setelah melakukan eksplorasi pada halaman website, maka langkah selanjutnya yaitu mencari nama akun TikTok dari masing-masing vendor smartphone. Pastikan semua vendor memiliki akun pada aplikasi sosial media TikTok .

\section{Menghitung Nilai Rata-Rata Variable Dari Top 5 Vendor Smartphone di Indonesia.}

Pada langkah ini, peneliti menghitung nilai variable video comments dan variable video likes. Variabel merupakan sesuatu yang memiliki nilai bervariasi dimana nilai tersebut dapat dijadikan sebagai dasar untuk empat data yang berbeda seperti rasio, skala, ordinal, nominal dan internal (Rankuti 2015). Untuk menghitung nilai rata-rata dari variabel video comments dan variabel video views yaitu dengan cara mengambil 10 postingan kemudian di hitung sehingga menemukan nilai rata-rata dari masing-masing variabel.

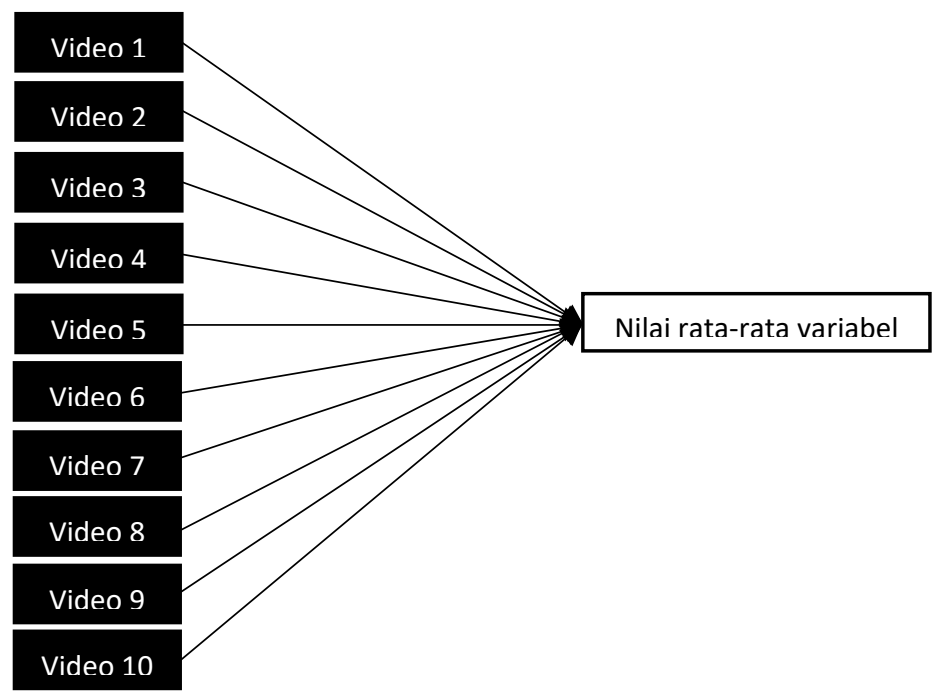

Gambar 1. Analisa Nilai Rata-Rata Variabel.

\section{Menghitung Nilai Kredibilitas Rasio}

Untuk menghitung nilai kredibilitas dari video comments to video views ratio, peneliti menggunakan cara membagi nilai pada variabel pertama dengan nilai variabel kedua. Jika video comments memiliki nilai 500 dan video likes memiliki nilai 1.000.000, maka cara menghitungnya yaitu $500: 1.000 .000=0,0005$. Dengan begitu nilai dari video comments to video views ratio adalah 0,0005 .

\section{Menentukan Peringkat Pada Akun TikTok}

Pada langkah terakhir yang dilakukan pada penelitian ini yaitu menentukan peringkat pada masing-masing rasio yang ada. Pada penentuan peringkat perlu melihat karakteristik 
dari rasio yang di lakukakn penelitian. Jika karakteristik rasio merupakan rendah, maka objek yang memiliki nilai terendah akan mendapatkan angka 5 dan objek yang memiliki nilai tertinggi akan mendapatkan angka 1. Namun jika rasio memiliki karakteritik tinggi maka objek yang mendapatkan nilai tinggi akan mendapatkan angka 5 dan objek yang mendapatkan nilai terendah akan mendapatkan angka 1. Setelah mendapatkan hasil kredibilitas ratio maka dapat disimpulkan objek yang mana mendapatkan peringkat 1 sampai dengan peringkat 5 .

\section{HASIL DAN PEMBAHASAN}

Akun TikTok dari 5 Gamer Indonesia Yang Memiliki Jutaan Pengikut Di Youtube, diantaranya

\section{Jess No Limit}

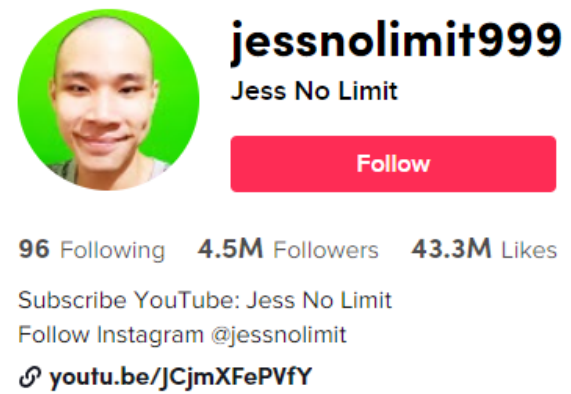

Gambar 1. Akun TikTok Jess No Limit

Sumber : https://www.tiktok.com/@jessnolimit999? (akses pada 21-10-2021)

\section{Frost Diamond}

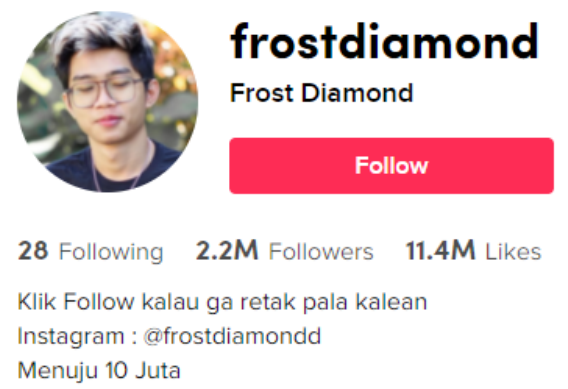

Gambar 2. Akun TikTok Frost Diamond 


\section{Miaw Aug}

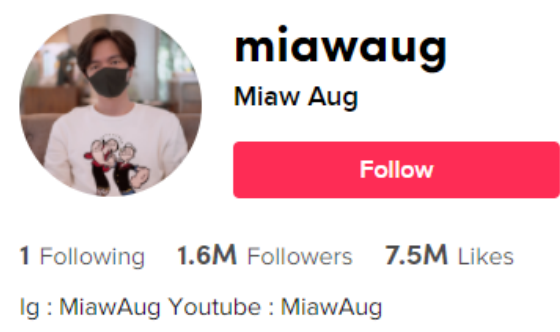

Gambar 3. Akun TikTok Miaw Aug

Sumber : https://www.tiktok.com/@ miawaug? (akses pada 21-10-2021)

\section{Dylan Pros}

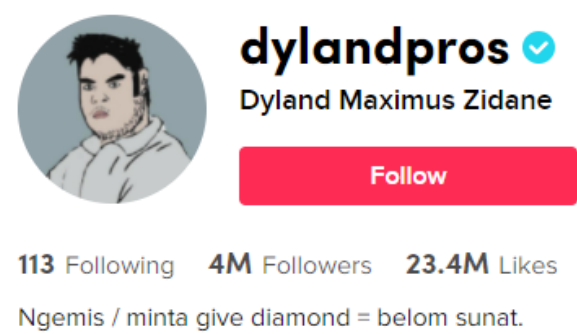

Gambar 4. Akun Tiktok Dylan Pros

Sumber : https://www.tiktok.com/@dylandpros? (akses pada 21-10-2021)

\section{Budi Gaming}

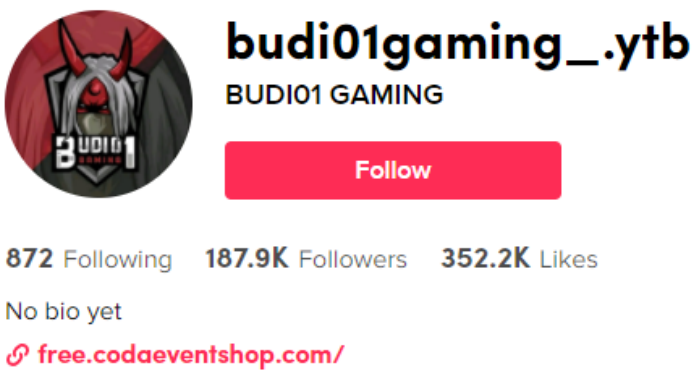

Gambar 5. Akun TikTok Budi Gaming

Sumber : https://www.tiktok.com/@budi01gaming_.ytb? (akses pada 21-10-2021) 
Dari kelima akun TikTok 5 Gamer Indonesia Yang Memiliki Jutaan Pengikut Di Youtube, peneliti menemukan nilai dari masing-masing variabel yang ada untuk menghitung rasio Video Comments to Video Likes dari setiap akun. Pada akun TikTok terdapat 7 variabel, diantaranya yaitu :

1. Likes

2. Followers

3. Following

4. Video Likes

5. Video Comments

6. Video Share

7. Video Views

Dari ketujuh variabel tersebut peneliti hanya fokus untuk menemukan hasil dari 2 variabel, yaitu :

1. Video Comments

2. Video Likes

Dari kedua variabel tersebut kemudian dianalisa sehingga menemukan nilai rata-rata dari variabel video comments dan variabel video likes. Untuk menghitung nilai rata-rata dari variabel video comments dan variabel video likes yaitu dengan cara mengambil minimal 10 postingan kemudian di hitung sehingga menemukan nilai rata-rata dari masing-masing variabel. Berikut merupakan tabel nilai rata-rata dari masing-masing Gamer, yaitu :

Tabel 1. Analisa Nilai Rata-Rata Nilai Variabel Video Comments dan Video Likes Akun Jess No Limit

\begin{tabular}{|c|r|r|}
\hline \multicolumn{3}{|c|}{ Jess No Limit } \\
\hline No & Video Likes & \multicolumn{1}{c|}{ Video Comment } \\
\hline 1 & 9,657 & 428 \\
\hline 2 & 31,200 & 1,003 \\
\hline 3 & 61,800 & 1,651 \\
\hline 4 & 690,500 & 6,429 \\
\hline 5 & 502,300 & 3,256 \\
\hline 6 & 673,100 & 4,397 \\
\hline 7 & 113,200 & 2,961 \\
\hline 8 & 101,900 & 793 \\
\hline 9 & 81,800 & 598 \\
\hline 10 & 82,500 & 1,024 \\
\hline Total & $\mathbf{2 3 4 , 7 9 6}$ & $\mathbf{2 , 2 5 4}$ \\
\hline
\end{tabular}


Tabel 2. Analisa Nilai Rata-Rata Nilai Variabel Video Comments dan Video Likes Akun Frost Diamond

\begin{tabular}{|c|r|r|}
\hline \multicolumn{3}{|c|}{ Frost Diamont } \\
\hline No & Video Likes & \multicolumn{1}{c|}{ Video Comment } \\
\hline 1 & 236,800 & 4,425 \\
\hline 2 & 315,500 & 0 \\
\hline 3 & 191,200 & 0 \\
\hline 4 & 115,000 & 0 \\
\hline 5 & 232,700 & 0 \\
\hline 6 & 563,200 & 0 \\
\hline 7 & 484,200 & 9,689 \\
\hline 8 & 285,500 & 5,057 \\
\hline 9 & 200,400 & 4,524 \\
\hline 10 & 229,300 & 4,954 \\
\hline Total & 285,380 & $\mathbf{2 , 8 6 5}$ \\
\hline
\end{tabular}

Tabel 3. Analisa Nilai Rata-Rata Nilai Variabel Video Comments dan Video Likes Akun Miaw Aug

\begin{tabular}{|c|r|r|}
\hline \multicolumn{3}{|c|}{ MiawAug } \\
\hline No & Video Likes & \multicolumn{1}{c|}{ Video Comment } \\
\hline 1 & 132,000 & 2,858 \\
\hline 2 & 194,300 & 739 \\
\hline 3 & 87,600 & 2,624 \\
\hline 4 & 79,500 & 2,261 \\
\hline 5 & 61,900 & 1,563 \\
\hline 6 & 59,400 & 1,102 \\
\hline 7 & 158,000 & 2,974 \\
\hline 8 & 271,800 & 5,871 \\
\hline 9 & 72,600 & 775 \\
\hline 10 & 793,200 & 8,337 \\
\hline Total & $\mathbf{1 9 1 , 0 3 0}$ & $\mathbf{2 , 9 1 0}$ \\
\hline
\end{tabular}


Tabel 4. Analisa Nilai Rata-Rata Nilai Variabel Video Comments dan Video Likes Akun TikTok Dylan Pros

\begin{tabular}{|c|r|r|}
\hline \multicolumn{3}{|c|}{ Dylan Pros } \\
\hline No & Video Likes & \multicolumn{1}{c|}{ Video Comment } \\
\hline 1 & 110,600 & 1,534 \\
\hline 2 & 210,200 & 4,666 \\
\hline 3 & 53,300 & 1,799 \\
\hline 4 & 146,500 & 1,895 \\
\hline 5 & 54,200 & 771 \\
\hline 6 & 75,500 & 2,816 \\
\hline 7 & 87,600 & 2,484 \\
\hline 8 & 823,600 & 11,500 \\
\hline 9 & 324,100 & 7,013 \\
\hline 10 & 36,200 & 895 \\
\hline Total & $\mathbf{1 9 2 , 1 8 0}$ & $\mathbf{3 , 5 3 7}$ \\
\hline \multicolumn{3}{|c|}{ Sumber : Pengolah Data Excel } \\
\hline
\end{tabular}

Tabel 5. Analisa Rata-Rata Nilai Variabel Video Comments dan Video Likes Akun TikTok Budi Gaming

\begin{tabular}{|c|r|r|}
\hline \multicolumn{3}{|c|}{ Budi01 Gaming } \\
\hline No & Video Likes & \multicolumn{1}{|c|}{ Video Comment } \\
\hline 1 & 14,100 & 816 \\
\hline 2 & 8,983 & 242 \\
\hline 3 & 14,200 & 280 \\
\hline 4 & 13,200 & 253 \\
\hline 5 & 19,700 & 197 \\
\hline 6 & 13,200 & 140 \\
\hline 7 & 9,984 & 357 \\
\hline 8 & 7,964 & 90 \\
\hline 9 & 10,400 & 120 \\
\hline 10 & 8,900 & 98 \\
\hline Total & $\mathbf{1 2 , 0 6 3}$ & $\mathbf{2 5 9}$ \\
\hline
\end{tabular}

Sumber : Pengolah Data Excel

Setelah menghitung nilai rata-rata tersebut, maka akan menemukan hasil akhir nilai rata-rata dari variabel video comments dan video likes 
Tabel 6. Nilai Variabel Pada Akun TikTok 5 Gamer Indonesia Yang Memiliki Jutaan Pengikut Di Youtube

\begin{tabular}{|c|r|r|}
\hline VARIABLE & VIDEO LIKE & \multicolumn{1}{|c|}{ VIDEO COMMENT } \\
\hline Jess No Limit & 234,796 & 2,254 \\
\hline Frost Diamont & 285,380 & 2,865 \\
\hline Miaw Aug & 191,030 & 2,910 \\
\hline Dylan Pros & 192,180 & 3,537 \\
\hline Budi 01 Gaming & 12,063 & 259 \\
\hline
\end{tabular}

Pada akun TikTok terdapat 17 rasio yang relevan digunakan untuk mengukur kredibilitas pada masing-masing akun. Namun pada penelitian kali ini hanya berfokus untuk menghitung Video Comments to Video Likes Ratio. Untuk menghitung kredibilitas dari masing-masing akun TikTok setiap Gamer, peneliti menghitung dengan cara : variabel 1 akan dibagi dengan variabel 2 , sehingga ditemukan hasil analisisa dari rasio tersebut.

Tabel 7. Hasil Perhitungan Rasio Akun TikTok

\begin{tabular}{|c|c|}
\hline VARIABLE & Video Comments to Video Likes Ratio \\
\hline Jess No Limit & 0.00959982 \\
\hline Frost Diamont & 0.01003925 \\
\hline Miaw Aug & 0.01523321 \\
\hline Dylan Pros & 0.01840462 \\
\hline Budi 01 Gaming & 0.02147061 \\
\hline
\end{tabular}

Video Comments to Video Likes Ratio memiliki karakteristik yang tinggi, artinya semakin tinggi nilai yang dihasilkan maka semakin baik kredibilitas dari performa akun tersebut. Untuk memberikan peringkat pada masing-masing Gamer, peneliti memberikan angka 1 kepada gamer yang mendapatkan nilai tertinggi dan angka 5 untuk gamer yang mendapatkan nilai terendah. Berikut merupakan tabel urutan nilai yang dihasilkan oleh masing-masing Gamer. 
Tabel 8. Nilai Rasio Akun TikTok 5 Gamer Indonesia Yang Memiliki Jutaan Pengikut Di Youtube

\begin{tabular}{|c|c|c|c|l|l|}
\hline \multirow{2}{*}{ RATIO } & \multicolumn{5}{|c|}{ NILAI } \\
\cline { 2 - 6 } & $\begin{array}{l}\text { Jess No } \\
\text { Limit }\end{array}$ & $\begin{array}{l}\text { Frost } \\
\text { Diamond }\end{array}$ & $\begin{array}{l}\text { Miaw } \\
\text { Aug }\end{array}$ & $\begin{array}{l}\text { Dylan } \\
\text { Pros }\end{array}$ & $\begin{array}{l}\text { Budi } \\
\text { Gaming }\end{array}$ \\
\hline $\begin{array}{l}\text { Video Comments to } \\
\text { Video Likes Ratio }\end{array}$ & 1 & 2 & 3 & 4 & 5 \\
\hline
\end{tabular}

Sumber : Pengolah Data Excel

Dari Tabel Nilai Rasio Akun TikTok 5 Gamer Indonesia Yang Memiliki Jutaan Pengikut Di Youtube dapat simpulkan bahwa Jess No Limit mendapatkan nilai tertinggi untuk rasio Video Comments to Video Likes. Sedangkan akun TikTok Budi Gaming mendapatkan nilai terendah untuk rasio ini. Jadi, pada penelitian ini Jess No Limit memiliki kredibilitas performa yang lebih baik dibandingkan dengan Gamer lainnya yang lainnya.

\section{KESIMPULAN}

Tujuan dari penelitian ini adalah mengetahui kredibilitas performa dari akun TikTok 5 Gamer Indonesia Yang Memiliki Jutaan Pengikut Di Youtube menggunakan Video Comments to Video Likes Ratio. 5 Gamer tersebut diantaranya : Jess No Limit, Frost Diamond, Miaw Aug, Dylan Pros, Budi Gaming. Dari kelima gamer youtube tersebut dapat disimpulkan bahwa :

1. Peringkat pertama diraih oleh Jess No Limit dengan nilai tertinggi yaitu 0.00959982

2. Peringkat kedua diraih oleh Frost Diamond dengan nilai 0.01003925

3. Peringkat ketiga diraih oleh gamer Miaw Aug dengan nilai 0.01523321

4. Peringkat keempat diraih oleh gamer Dylan Pros dengan nilai 0.01840462

5. Peringkat kelima diraih oleh gamer Budi Gaming dengan nilai terendah yaitu 0.02147061 


\section{DAFTAR PUSTAKA}

Agustina, Winnie, and Wulan Purnama Sari. 2021. "Pengaruh Influencer Marketing Tiktok Terhadap Brand Image Bittersweet by Najla." Prologia 5 (2). https://doi.org/10.24912/pr.v5i2.10211.

I Putu Hendika Permana, and Ni Putu Suci Meinarni. 2021. "Ratio Analysis on Tiktok (Social Media) for Qualitative Research Using Explorative Methods." Jurnal Ekonomi \& Bisnis JAGADITHA 8 (1). https://doi.org/10.22225/jj.8.1.2944.30-38.

Imron, R. M. 2018. "TikTok Jadi Aplikasi Terbaik Di Play Store.” 2018. https://inet.detik.com/mobileapps/d4329137/tiktok-jadi-aplikasiterbaik-di-playstore.\%0D.

Kusuma, P. W. 2020. “Di Balik Fenomena Ramainya TikTok Di Indonesia.” 2020. https://tekno.kompas.com/read/2020\%0A/02/25/11180077/di-balikfenomena-ramainyatiktok-diindonesia?page $=$ all\%0D.

Maryam, Siti, Isrok'atun Isrok'atun, and Ani Nur Aeni. 2016. 'PENDEKATAN EKSPLORATIF UNTUK MENINGKATKAN KEMAMPUAN REPRESENTASI MATEMATIS DAN KEPERCAYAAN DIRI SISWA.” Jurnal Pena Ilmiah 1 (1): 55160. https://doi.org/10.23819/PI.V1I1.2984.

Purnamasari, Nurjihan Pricillia, and Ririn Puspita Tutiasri. 2021. “Analisis Resepsi Remaja Perempuan Terhadap Gaya Hidup Berbelanja Fashion Melalui Tayangan Video 'Belanja Gak Aturan' Dalam Akun Tiktok @handmadeshoesby.” Jurnal Representamen 7 (01). https://doi.org/10.30996/REPRESENTAMEN.V7I01.5129.

Putri, Dwi, and Robiatul Adawiyah. 2020. “7504-22835-1-Pb” 14 (2): 135-48.

Putri, Shani Dwi, and Suzy Azeharie. 2021. "Strategi Pengelolaan Komunikasi Dalam Membentuk Personal Branding Di Media Sosial Tiktok.” Koneksi 5 (2): 280-88. https://doi.org/10.24912/KN.V5I2.10300.

Rankuti, Freddy. 2015. "Buku Riset Pemasaran.” 2015. 